\title{
DOCUMENTING A COMPLEX MODERN HERITAGE BUILDING USING MULTI IMAGE CLOSE RANGE PHOTOGRAMMETRY AND 3D LASER SCANNED POINT CLOUDS
}

\author{
Maria Lucia Vianna Baptista \\ Documenta Fotogrametria Arquitetural \\ www.documenta-mlvb.com \\ maluvbb@gmail.com
}

Commission V, WG V/2

KEY WORDS: Modern Heritage Buildings, Architectural survey for Restoration, Building pathology Mapping, 3D Laser scanning and Architectural Photogrammetry, Docomomo

\begin{abstract}
:
Integrating different technologies and expertises help fill gaps when optimizing documentation of complex buildings. Described below is the process used in the first part of a restoration project, the architectural survey of Theatre Guaira Cultural Centre in Curitiba, Brazil. To diminish time on fieldwork, the two-person-field-survey team had to juggle, during three days, the continuous artistic activities and performers' intense schedule. Both technologies (high definition laser scanning and close-range photogrammetry) were used to record all details in the least amount of time without disturbing the artists' rehearsals and performances. Laser Scanning was ideal to record the monumental stage structure with all of its existing platforms, light fixtures, scenery walls and curtains. Although scanned with high-definition, parts of the exterior façades were also recorded using Close Range Photogrammetry. Tiny cracks on the marble plaques and mosaic tiles, not visible in the point clouds, were then able to be precisely documented in order to create the exterior façades textures and damages mapping drawings. The combination of technologies and the expertise of service providers, knowing how and what to document, and what to deliver to the client, enabled maximum benefits to the following restoration project.
\end{abstract}

\section{HERITAGE BUILDINGS X MODERN ARCHITECTURE}

Our tangible cultural heritage (buildings, monuments, landscapes, books, works of art, and artefacts) is defined as having architectural, historical and artistic significance. In the last century, in some developing countries the word "progress" was associated with demolishing the old to construct new structures. Following the above definition, some buildings were not old enough to be considered "heritage", and many unique examples were lost. In 1988 two Dutch architects initiated a non-profit organization called DOCOMOMO International (International Committee for Documentation and Conservation of buildings, sites and neighbourhoods of the Modern Movement) being one of its missions to create global awareness in recognizing modern architecture buildings as part of cultural heritage. At present it has more than 2300 interdisciplinary members from all over the World.

In 1948, in Curitiba, South of Brazil, a Cultural Complex project was commissioned to Engineer-Architect Rubens Meister (1922-2009). Construction began in 1952, occupying an area of approximately $16,900 \mathrm{~m}^{2}$ in the city centre. The Complex construction took two decades. Inauguration of the Theatre Guaira in April 1971 was postponed when, a few weeks before its opening day, an arson fire consumed the brand new Big Auditorium, only to re-open on December 1974. The Theatre Complex houses three Auditoria with 2,757 seats capacity, a renowned Ballet Company, Fine Arts Exposition Rooms, the Symphonic Orchestra of Paraná headquarters and the Centro Cultural Teatro Guaira Administration. It was designated heritage building in 2003 as one of the first Modern Architecture buildings in the State of Paraná. With insufficient maintenance for many years, the building today is in precarious and outdated conditions to proper function as an important Arts and Entertainment Centre. After continuous requests from the artistic community and the civil society, a bid for a restoration and theatre modernization project was authorized in 2012.

\section{ARCHITECTURAL PHOTOGRAMMETRY OR LASER SCANNING?}

Close Range Photogrammetry was considered for many decades as the most impressive technology to precisely document a building. Expensive equipment restricted its use mainly to Universities and Government Institutions. Although showing many advantages for documenting and surveying buildings, few Architectural Schools had and many still don't have this discipline on their regular curriculum. Photogrammetry was mostly known by cartographers and engineers, and usually most used for mapping purposes.

When laser scanning took the central stage in the first years of XXI century, many thought that Close Range Photogrammetry days were over. Some people took sides, and finally got to a common sense that there is room for everyone. Each technology has advantages above the other, and the use of both together is what is needed to do a more precise and detailed architectural survey of a heritage building.

\section{THE IMPORTANCE OF PLANNING AHEAD}

For each new survey project of a heritage building, since each one is particularly unique, there must be a cautious planning. 
As the architectural survey is one of the first steps on a documentation project, together with historical and iconographic research about the surveyed object, usually a project is contracted when the deadline to deliver the survey is already too short. The use of modern technologies as laser scanning and architectural photogrammetry allow the delivery of very precise and fast products. But even though the needed time is still longer than contractors would wish, the final product is extremely better and faster than when done by the traditional manual surveys.

In the Theater Guaira project, we had to follow the fully booked Theatre agenda. We divided the huge task in four parts: two for the exterior surveys, with all façade elevations and roof, and two for the interior surveys for both Auditoria. Due to budget constraints, the smaller rooms and one small Auditoria were left out of our responsibility.

Located in one of the busiest Squares in the city, we began the exterior survey on a Sunday, early in the morning, when fewer public buses and cars would pass by the area. Even though every Sunday morning there is a Symphonic Orchestra Concert, we could organize to have less interference from pedestrians in the building scanning process.

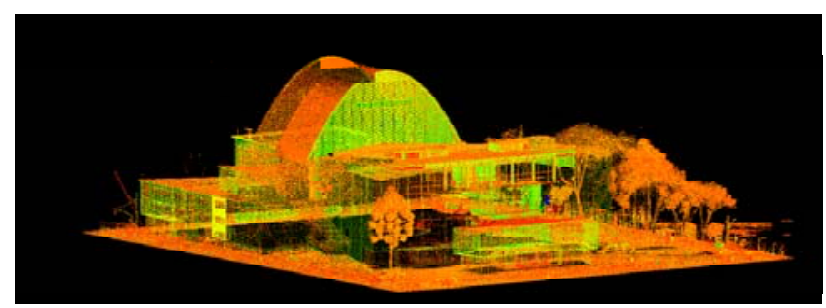

Figure 1. Registered high density Point Clouds - Exterior Façades

Laser scanning of the two different Auditoria were done assuring that common points from both interior and exterior surveys were taken to allow the registration of many point clouds on a single 3D Model, resulting on a 13GB file.

After finishing all scanning work, we carefully reviewed each point of the 3D model to decide which part would need more detailed survey, done by close range photogrammetry. One technology complementing the other. A Leica Geosystems ScanStation C10 was used for scanning, executed by Terrascan Engenharia. Close Range Photogrammetry was done with a Rolleimetric camera and Rollei CDW software. A detailed photography survey and 27 AutoCad drawings were delivered.

\section{COMPLEMENTING TECHNOLOGIES}

In the Main Auditorium, the huge stage walls and ceiling had a matte black paint, had all the scenery panels, curtains, light fixtures, platforms, ropes and so many equipments that we couldn't see what lies behind. It was easily surveyed with the laser scanner.

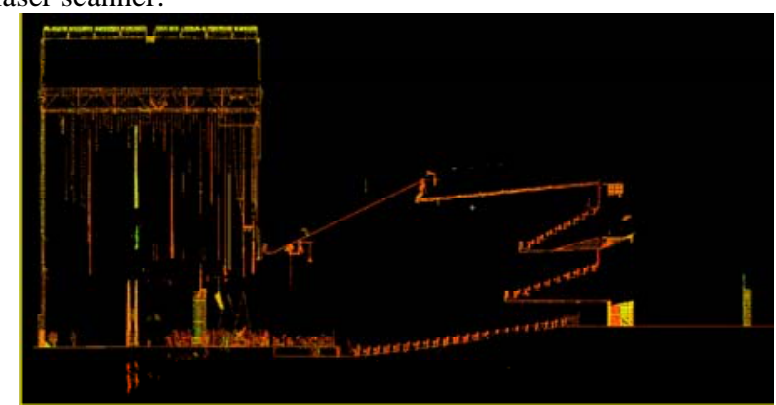

Figure 2. Point Clouds in “Big Auditorium Guairão” Longitudinal Section
The Big Auditorium scanning was completed during the Symphonic Orchestra rehearsal (Figure 2).

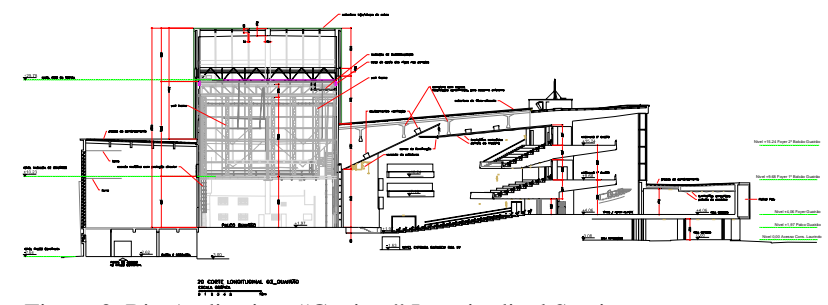

Figure 3. Big Auditorium “Guairão” Longitudinal Section

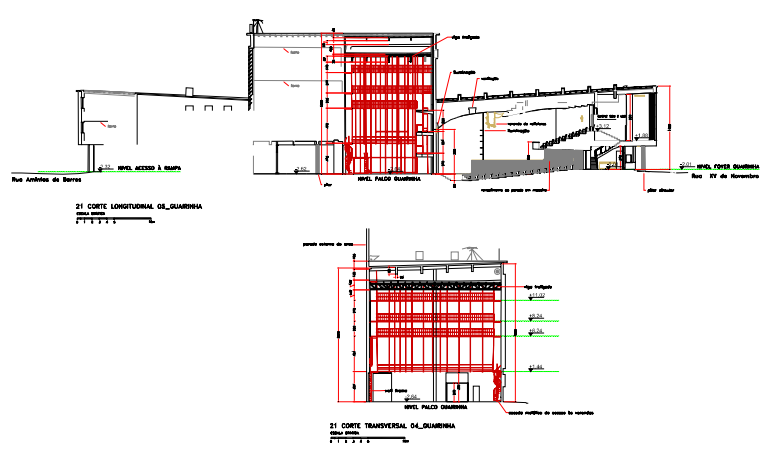

Figure 4. Small Auditorium “Guairinha” - Longitudinal and Transversal Sections

The small $2 \mathrm{x} 2 \mathrm{~cm}$ tiles on the exterior façades of the stage arch, the structural and pollution-caused damages, cracks and humidity spots on concrete and marble plaques, didn't show very well in the point clouds. When you zoom into the point clouds to draw little details, even if it is scanned with high density points, sometimes you do not have a good visualization of it. (Figure 6)

In this case, for part of the walls and also for the concrete art panel from Poty Lazarotto located in the main façade of the Theatre, photogrammetry was a better choice in terms of details visualization. (Figure 10)

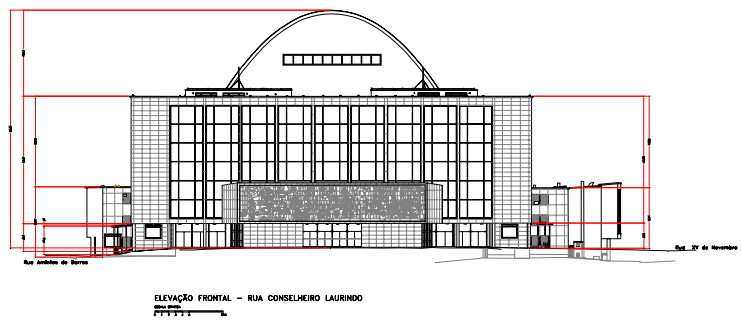

Figure 5. Front Elevation_Main Entrance with Poty Lazarotto’ concrete art panel

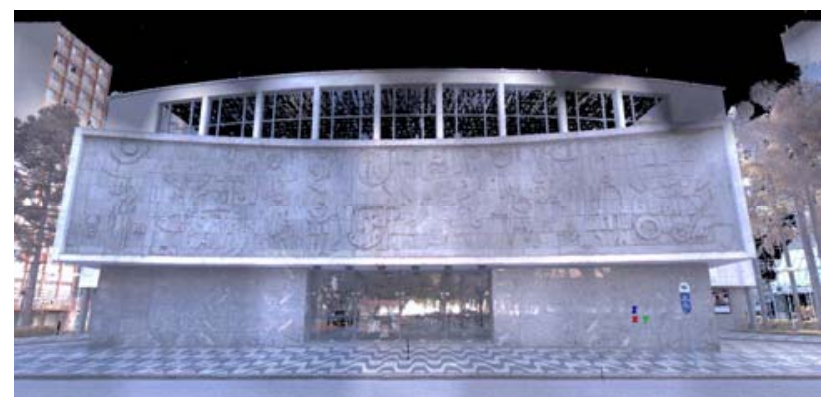

Figure 6. Point Clouds in perspective with Image Texture Map of the Front Elevation_Main Entrance with Poty Lazarotto’ concrete art panel 


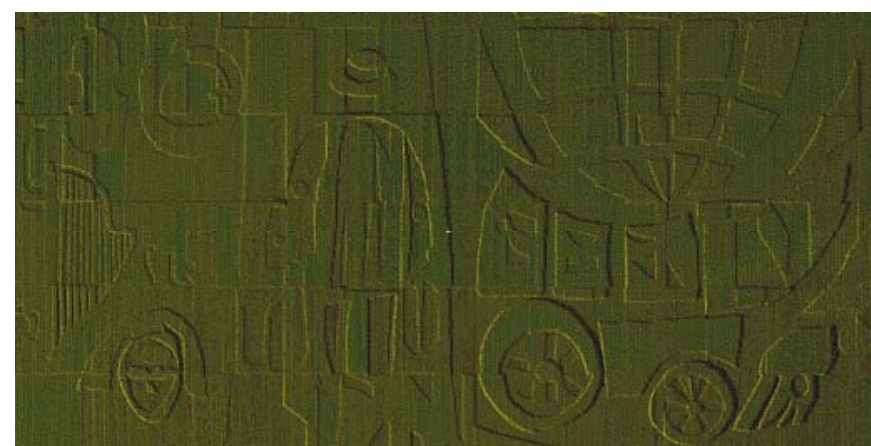

Figure 7. 'Intensity Map’ Point Cloud of Poty Lazarotto art panel.

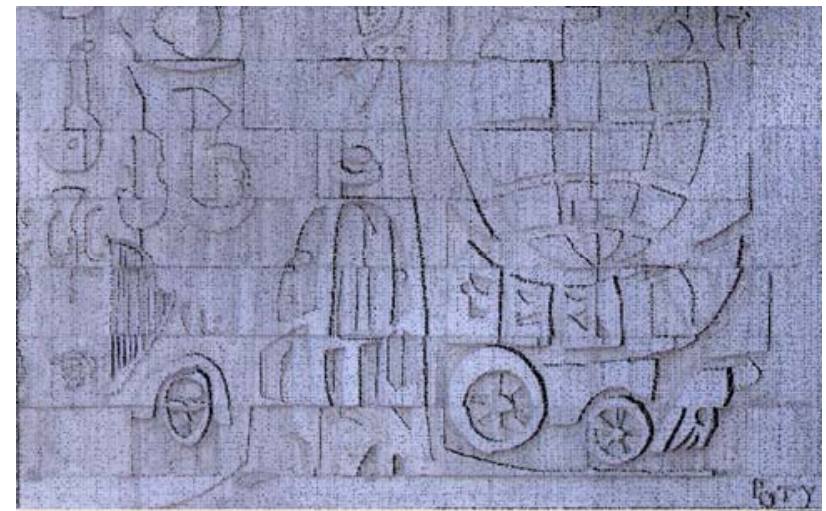

Figure 8. ‘Image Texture Map’ Point Cloud

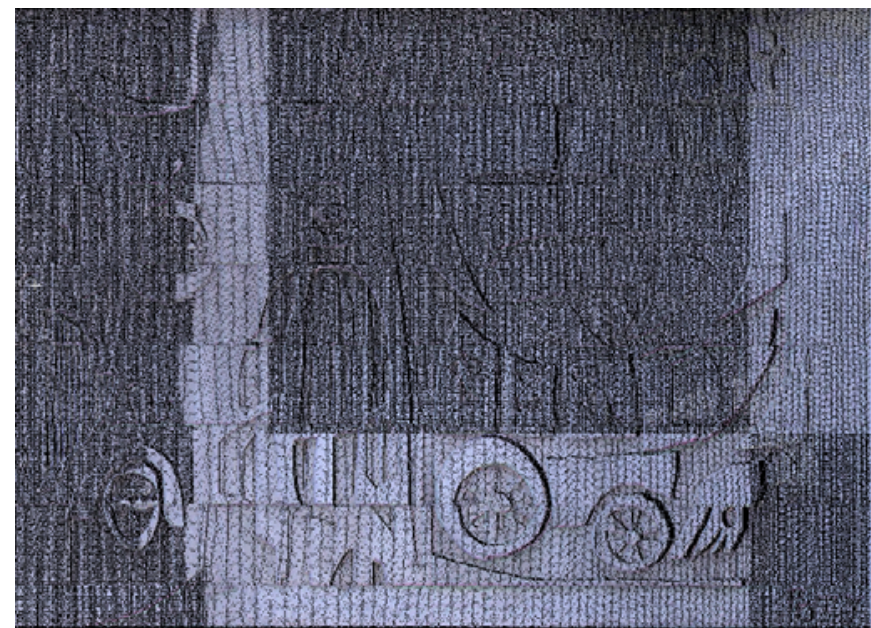

Figure 9. Poor details visualization when zooming into a 'Colours from Scanner' Point Cloud

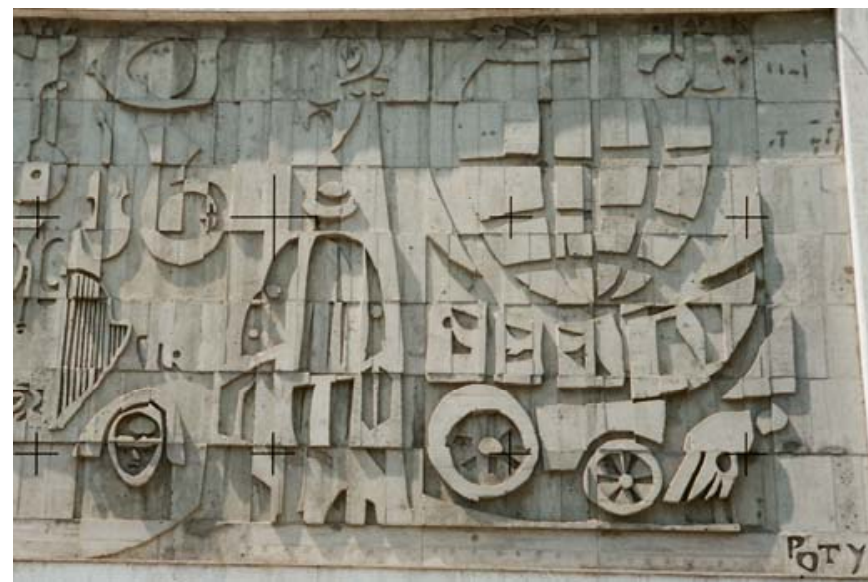

Figure 10. High resolution photograph taken with a close-range photogrammetric camera

\section{BUILDING PATHOLOGIES MAPPING}

Photogrammetry was definitely the best option to complete the Damages Mapping drawings (building pathologies mapping) on top of the final architectural drawings. In the pictures we can easily identify humidity marks, growing plants on small holes and cracks, different textures, missing or broken parts.

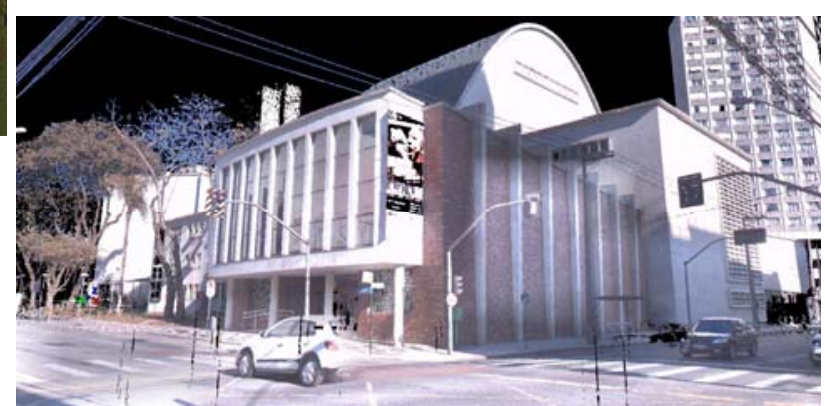

Figure 11. Image Texture Map on Point Clouds: structural faults and tiny cracks on walls were not visible

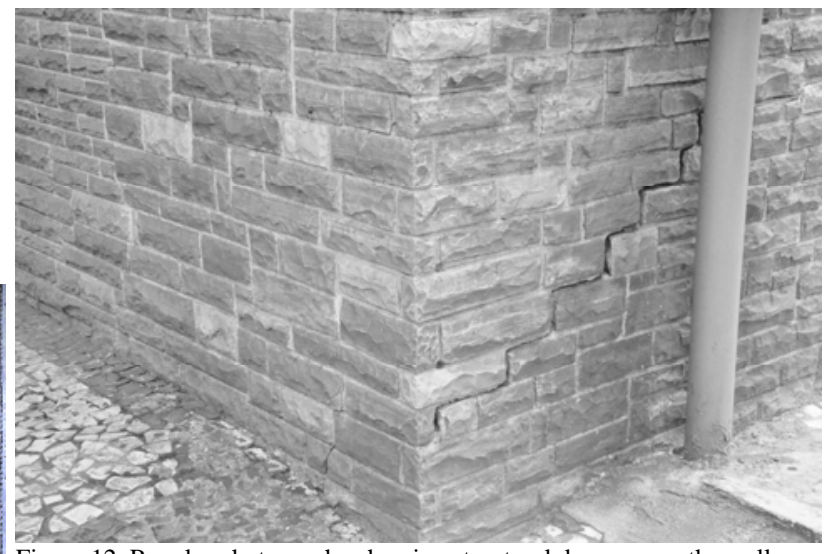

Figure 12. Regular photography showing structural damages on the wall

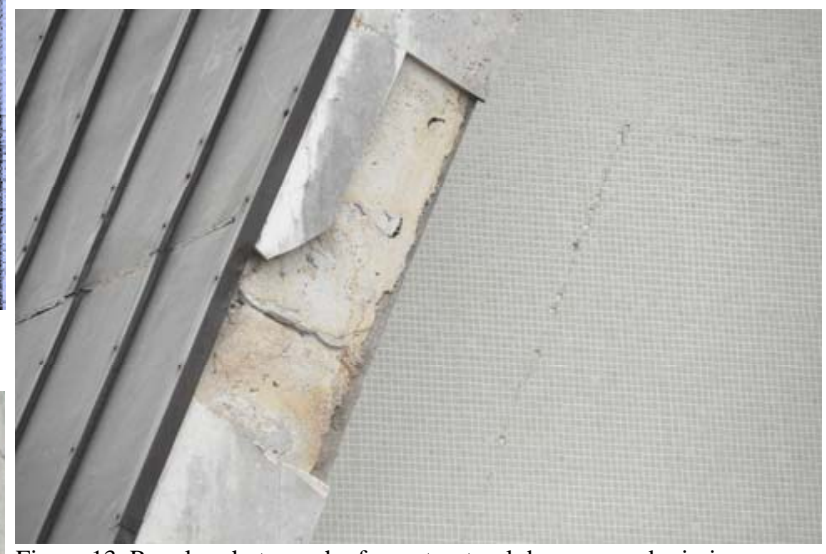

Figure 13. Regular photography from structural damages and missing or broken marble plaques

\section{CONCLUSION}

The importance of preservation of Cultural Heritage in general gained in the last years a higher status. If not for keeping the economy growing (Heritage commercial tourism) but also because of the many natural disasters that are happening more frequently, and some man-made catastrophes which reduced to nothing many beautiful heritage monuments. 
We need to invest on building skilled heritage conservation professionals to help to keep up with the escalating technology advances.

Many new possibilities for precise and accurate heritage documentation emerge every year, especially for data capture with digital imagery, with photogrammetry and laser scanning being more and more used worldwide. It is necessary to develop professional skills to cope with the technological advancement, to analyze and present the acquired data on an efficient way to be used by heritage conservation professionals. Each profession has its own requirements and needs, and there is no point on having all the available technology if the resulting documentation doesn't fill the needs of those who will effectively do the preservation work.

Sometimes even the professionals responsible for the restoration of a heritage building don't know what to expect from a precise architectural survey done with laser scanner or photogrammetry, or even what to ask for when contracting such a service. This lack of communication results on precious time and resources being lost or misused.

The need for good communication between everyone involved is essential for good project results. The products delivered, such as this architectural survey that used high-technology to be produced, have to fill the need of architects doing the following restoration projects, have to be understood by other professionals involved in the complementary projects (electrical, structural, etc), have to be useful for the building overall management. Ideally, the architectural documentation should be used entirely, and be open to receive more layers of information as needed, since all information is already captured by the scanning and photogrammetric processes. This thorough comprehension is only obtained through deep information on the topics and good communication between the parties.

\section{REFERENCES}

Blake, W.H., 2010, What is the future of metric Heritage Documentation and its skills?, International Archives of Photogrammetry, Remote Sensing and Spatial Information Sciences, Vol. XXXVIII, Part 5, Commission 5 Symposium, Newcastle upon Tyne, UK., pp 98-102

Bruschke, A., 2011, Architectural Survey in Practice, XXIII CIPA Symposium, Prague, Czech Republic

Cannataci, J.A. et al., 2012, E-Heritage: The future for integrated applications in Cultural Heritage, The International Archives of Photogrammetry, Remote Sensing and Spatial Information Sciences, Vol. 34, Part XXX, Melbourne, Australia

Grussenmeyer, P., et all., 2012, Recording approach of Heritage sites based on merging point clouds from High Resolution Photogrammetry and Terrestrial Laser Scanning, International Archives of the Photogrammetry, Remote Sensing and Spatial Information Sciences, Volume XXXIX-B5, pp 553558, Melbourne, Australia

Jacobs, G., October 2011, Terminology: "Scanning” or “HiDef”?, Professional Surveyor Magazine, www.profsurv.com

Jacobs, G., September 2010, 3D Scanning: The context benefit, Professional Surveyor Magazine, www.profsurv.com

Jordá, F., et al., 2011, Close-Range Photogrammetry and Terrestrial Laser Scanning: High resolution texturized 3D
Model of the Chapel of the Kings in the Palencia Cathedral as a case study, XXIII CIPA Symposium, Prague, Czech Republic

Koch, M., Kaehler, M., 2009, Combining 3D Laser-Scanning and Close-Range Photogrammetry - An approach to exploit the strenght of both methods, Computer Applications to Archaeology, Williamsburg, Virginia USA

Mealy, C., Elbe, B., 2012, Restoring the Cincinnati Music Hall using 3D Laser Scanning Technology, Spar Point Group, www.sparpointgroup.com

Nex, F., Rinaudo, F., Photogrammetric and Lidar integration for the Cultural Heritage metric surveys, International Archives of Photogrammetry, Remote Sensing and Spatial Information Sciences, Vol. XXXVIII, Part 5, Commission 5 Symposium, Newcastle upon Tyne, UK., pp 490-495 